\title{
The Impact Of Cash Flow Information On The Forecasts Provided By Financial Analysts, Considering The Quality Of Earnings
}

Sylvie Deslauriers, (Email: sylvie_deslauriers@uqtr.ca), Université du Québec à Trois-Rivières, Canada

\begin{abstract}
In the present study, the impact of publishing more precise and better-structured cash flow information on financial analysts' forecast will be examined. Even though the change in standards presently under study may be principally deemed to be cosmetic, it does appear to have allowed financial analysts to generate more accurate forecasts of future earnings. An increase in the dispersion of these forecasts, more especially when dealing with enterprises providing a high quality of earnings, is also noted.
\end{abstract}

\section{Introduction}

\subsection{Utility of cash flow information}

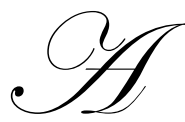

great deal of literature focuses on the use of information on cash flows when determining the value of an enterprise and its securities. Two major approaches may be noted, one based on cash flows, the other on earnings, both long viewed as rival alternatives. The debate is still very much alive today, since empirical results are less persuasive when information on cash flows is related to the capital market. Barlev and Livnat (1990) have pointed out a significantly stronger relationship between various ratios and stock returns following the inclusion of the statement of changes in financial position in 1971. Wilson (1987) identified a significant association between stock returns and unexpected cash flows from operations. Although the study by Bowen, Burgstahler and Daley (1987) comes to the same conclusion, Bernard and Stober (1989) were unable to reproduce Wilson's (1987) results. After checking out the impact of information on earnings, Cheng, Liu and Schaefer (1997) and Charitou, Clubb and Andreas (2001) suggest the existence of a link between information on cash flows and the market price of the securities. Previously, Ali (1994) had obtained similar results, but for one part of the sample only. Like Kochanek and Norgaard (1988), a number of researchers believe that information on cash flows could become a more critical factor in certain circumstances, more especially for an enterprise in financial difficulty. Studying this context, Hanna (1993) noted a more significant relationship between unexpected cash flows and abnormal returns. When identifying enterprises that had filed for bankruptcy, Rujoub, Cook and Hay (1995) and Huyghebaert, Gaeremynck, Roodhooft and Van de Gucht (2000) concluded that information concerning cash flows is more useful than traditional measures based on the accrual accounting method.

Taking into account the previous discussion, we might come to the conclusion that information on cash flows is complementary to information on earnings and should not necessarily be seen as a competitive alternative. According to Healy and Palepu (1993, p. 7), "Superior analysts adjust reported accrual numbers, if necessary, to reflect economic reality, perhaps by using the cash flow statement and the footnote disclosure." This means that information concerning cash flows may help the user of financial statements to better understand the content of the income statement and better assess the ability of the enterprise to maintain or improve earnings in the future. For

Readers with comments or questions are encouraged to contact the author via email. 
example, according to O'Glove (1987), Neill, Schaefer, Bahnson and Bradbury (1991), Tergesen (2001) and Boyd and Cortese-Danile (2001), earnings could be deemed to be of higher quality when they are accompanied by greater cash flows and vice versa. Atrill (2001) and Mills, Bible and Mason (2002) reiterate the importance of considering cash flows when assessing the viability of an enterprise.

Currently, financial analysis is a process in which, amongst other things, little is known as regards the choice and importance given to the various components of accounting information. Yet financial analysts are often considered to be a group of sophisticated users of information, representing the various market users. They also leave behind them observable traces of their work, since they regularly publish Earnings per share forecasts. Error (inaccuracy) in their forecasts reflects the forecasting ability of the financial analysts, and the dispersion of their forecasts corresponds to the divergence of beliefs of those who prepare them. A number of researchers (Brown, Richardson and Schwager (1987), Kross, Ro and Schroeder (1990) and McEwen and Hunton (1999)) suggest that financial analysts tend to analyze and take into consideration a vast range of information, thus enhancing the accuracy of their financial forecasts. Brown and Han (1992) and Ali, Klein and Rosenfeld (1992) have mentioned that the publication of annual earnings improves the homogeneity of earnings forecasts for the following financial period. As for Stickel (1989), he noted that financial analysts anticipate and respond to interim earnings statements by revising their own forecasts.

A number of research papers have discussed the impact of specific changes in accounting policies on the forecasts generated by financial analysts, more especially as regards their accuracy. Most analysts see a significant relationship between a change of policies and forecasts of future earnings. However, we have been unable to locate any literature on cash flow information in this area. According to Elliott and Philbrick (1990), forecasts are more widely dispersed and less accurate during the year of an accounting policies change and the scope of any revision is linked to the impact of the scale of the change itself on earnings. Ricks and Hugues (1985) have looked at the adoption of the equity method with regard to long-term investments and have noted a significant correlation between the magnitude of this change and forecast error. Subsequently, Hugues and Ricks (1986) and Biddle and Ricks (1988) obtained similar results with regard, respectively, to enterprises that adopted the interest capitalization policy and those choosing the LIFO inventory method. Following the adoption of the policy requiring publication of segmented information, it would seem that forecasts are less widely dispersed (Swaminathan (1991)) and more accurate (Lobo, Kwon and Ndubizu (1998)). Chaney, Hogan and Jeter (1999) provide evidence that the analysts' accuracy declines in the year following the disclosure of restructuring charges. Finally, Ashbaugh and Pincus (2001) have noted a drop in forecasting errors subsequent to the adoption of International Accounting Standards.

\subsection{Standardization of accounting information on cash flows}

Information on cash flows is published in a separate financial statement: the cash flow statement. In Canada, accounting standards for this statement were revised in 1985 (CICA). Users of information on capital markets, including financial analysts, (Sondhi, Sorter and White, 1987), requested that emphasis be placed on "cash flows" rather than on "funds". Consequently, the first change in the policy consisted in limiting the definition of the term "fund", though most enterprises retain the expression "working capital". They no longer have any choice in the matter and must indeed explain variations in "liquidities" made up of cash and cash equivalents, in their cash flow statements. The second change concerns presentation of the reconciliation of net earnings and cash flows from operating activities. All non-cash income statement items and changes in all short-term non-cash items must be published. Prior to the change in policies, this latter part of the reconciliation was not required, since only the overall variation in working capital items was presented. Finally, the last change requires that information on cash flows be better structured and divided into three classes: operating activities, investing activities and financing activities. ${ }^{1}$ Previously, there were only two classes, one for "sources of funds" and the other for "use of funds", without taking into account the nature of the activities that generated their movement.

This change in accounting policy is very special, since it deals with the way in which information is presented, while supposing no change in the accounting treatment of operating, investing or financing activities. The first two changes make information on cash flows more precise and consequently more easily comparable from one enterprise to another. It should be noted, however, that accountants generally prepare the first section of cash flows from operating activities by looking specifically at the income statement and the balance sheet. Of course, there are 
now more details given with regard to changes in the working capital items, but it all boils down to the difference between opening balances and closing balances, as shown on the balance sheet. As for sections on cash flows from investing and financing activities, the information provided is the same as it was previous to any change of policy. It is henceforth better structured in three distinct classes instead of being scattered amongst the two categories: source of funds and use of funds.

In short, information on cash flows, as required under the terms of the new policies, was already available and reconcilable by an examination of the overall financial statements. However, this required a certain amount of time and a clear understanding of the presentation and the accounting treatment of financial operations. Drtine and Largay (1985) and Maksy (1988) have pointed out that analysis is easier and speedier when information is presented directly. In other words, thanks to the new policies, information on cash flows is more precise and better structured, but it is mainly a cosmetic change and does not really provide any new information.

Even though cash flow information does appear to be under consideration by the capital market, little research literature has been generated so far. In fact, the present empirical study has the distinction of concerning itself with market users of information and not with the movement of stock prices. To this end, the impact of information on cash flows is studied by a target group, the financial analysts themselves. The methodology used is very specific inasmuch as it considers the fact that information on cash flows can serve in the assessment of the quality of an enterprise's earnings. In this context, information could play a more determining role in extreme circumstances, such as those of an enterprise experiencing financial difficulties.

The present study, therefore, is focused on the impact of cash flow information on error and dispersion in financial analysts' forecasts, considering the quality of earnings.

\section{Hypotheses and methodology}

\subsection{Research hypotheses}

In this study, the extent of errors and dispersion in financial analysts' forecasts will be considered for the periods surrounding the change in policies regarding cash flow information, i.e. the pre-change, in-change and postchange periods. The new policies were to be applied to financial periods as of October 1, 1985 or following. Consequently, financial periods that began prior to October 1, 1985 are those of the pre-change period. Financial periods beginning between October 1, 1985 and September 30, 1986 are in-change and those beginning after October 1, 1986 are those of the post-change period. Derived from the foregoing we can now enunciate two null hypotheses:

$H_{0} A$ : Forecast error by financial analysts is the same for the pre-change, in-change and post-change periods.

$\boldsymbol{H}_{0} \boldsymbol{B}$ : Forecast dispersion by financial analysts is the same for the pre-change, in-change and post-change periods.

Forecast error is an average measurement of the variance between anticipated earnings and real earnings as forecast by the overall group of financial analysts, and this is a measurement expressed as an absolute value. A minor error, close to zero, means that the forecast is more accurate, and vice versa. The dispersion of the forecast corresponds to the coefficient of variation of all individual forecasts of financial analysts. A high level of dispersion means that the beliefs are heterogeneous and vice versa. Following publication of the annual financial statements for the pre-change, in-change and post-change periods, a calculation is made of the forecast error and dispersion. ${ }^{2}$ The objective is to study the impact of publishing the information on cash flows (available in the financial statements of a given period $(t)$ ) on financial analysts' earnings forecasts for the following period $(t+1)$.

\subsection{Approximation of the quality of earnings}

The role of cash flow information has already been mentioned in assessing the quality of earnings, more especially for enterprises showing signs of being in financial difficulty. Consequently, this study considers the capacity of an enterprise to convert its earnings into cash flows. The quality of the earnings is then approximated on the basis 
of the ratio between cash flows from operating activities and net earnings (net losses). ${ }^{3}$ The calculation of this ratio allows one to split the sample into four equal parts, which then become three sub-groups. The enterprises with the lowest coefficient, representing $25 \%$ of the sample, are deemed to have a low quality of earnings. Their weak cash flows, compared with earnings, make them more vulnerable and this is characteristic of enterprises that are in financial difficulties. This sub-group may be compared to samples from the previous studies devoted to the situation where operating the enterprise generally leads to using, rather than generating, cash flows. In fact, currently, there have been practically no empirical studies dealing with the other end of the scale, i.e. with enterprises whose financial health is greater than average. Consequently, enterprises with the highest cash flow coefficient as compared to earnings, another $25 \%$ of the sample, are considered to have a high quality of earnings. The isolation of the first two groups of enterprises meets the objective which was to focus on extreme situations where cash flow information might have more impact. Finally, the remaining enterprises, corresponding to $50 \%$ of the sample, are considered to have an acceptable quality of earnings, since the cash flow level is very close to the earnings level. ${ }^{4}$

\subsection{Enterprise sample}

The sample covers 135 enterprises, all of which are listed on one or other Canadian stock exchanges. The information published in the annual financial statements of these enterprises, i.e. operating cash flows and net earnings, is taken from the Stock Guide data base. In certain cases, the information was completed by manual examination of the financial statements in order to collate the available information, more especially for the first period required by the study, 1984. The analysis also takes into account the different year end of the enterprises and the data therefore refers to a financial period and not to a calendar year.

The financial forecasts of the financial analysts are available on the Institutional Brokers Estimate System («IBES») database. The Canadian segment of this includes, amongst other things, the individual forecast, the average forecast and the forecast dispersion for current period earnings. During the period under study, an average of 223 Canadian enterprises was observed by financial analysts. It was calculated that there was an average of 9.2 financial analysts per enterprise, with a number varying from 3 to 41 for each forecast. In order to be included in the sample, the enterprise has to be followed by a minimum of three financial analysts and be the subject of at least one forecast in each of the three 'change' periods. ${ }^{5}$

\section{Results}

\subsection{Description of sample}

Table 1 includes descriptive statistics of financial analysts' forecasts for the sample of enterprises as a whole, and then for the three separate sub-groups. The average and standard deviation for forecast error and dispersion are given for each period (pre-change, in-change and post-change) contiguous to the change of policies. With regard to the sample as a whole, the forecast error and dispersion are not the same from one period to another and the differences are particularly noticeable between the pre-change and in-change periods. It will be seen that forecast error is less during the change, indicating that the forecasts are more accurate, and remains roughly at the same level in the post-change period. With regard to forecast dispersion, it is higher during the in-change period, compared with the pre-change period. It drops slightly in the post-change period, but does not go down to the pre-change level.

Table 1 also brings out differences between the sub-groups, an observation that is reinforced by the results of a statistical test to this end. Financial forecast reliability, represented here by error and dispersion levels, is thus significantly different according to the quality of earnings. During the three periods under study, the level of error and dispersion in forecasts for enterprises with acceptable quality of earnings is the lowest, and drops from one period to the next. This means that financial analysts provide more accurate and more homogeneous forecasts for future earnings in enterprises where cash flows more closely match earnings. Consequently, it is more difficult to predict the future earnings of enterprises where the low or high quality of earnings is at one or other of the extreme limits. 
Table 1

Descriptive Statistics: Error and Dispersion in Financial Analysts' Forecasts

\begin{tabular}{|c|c|c|c|c|c|c|c|c|c|c|}
\hline \multirow{2}{*}{$\begin{array}{l}\text { financial } \\
\text { analysts' } \\
\text { forecasts }\end{array}$} & \multicolumn{2}{|c|}{$\begin{array}{l}\text { overall } \\
\text { sample }\end{array}$} & \multicolumn{2}{|c|}{$\begin{array}{l}\text { low quality } \\
\text { of earnings } 1\end{array}$} & \multicolumn{2}{|c|}{$\begin{array}{l}\text { high quality } \\
\text { of earnings } 1\end{array}$} & \multicolumn{2}{|c|}{$\begin{array}{l}\text { acceptable quality } \\
\text { of earnings } 1\end{array}$} & \multicolumn{2}{|c|}{$\begin{array}{c}\text { comparison } \\
\text { between sub-groups }\end{array}$} \\
\hline & average & $\begin{array}{l}\text { standard } \\
\text { deviation }\end{array}$ & average & $\begin{array}{l}\text { standard } \\
\text { deviation }\end{array}$ & average & $\begin{array}{r}\text { standard } \\
\text { deviation }\end{array}$ & average & $\begin{array}{l}\text { standard } \\
\text { deviation }\end{array}$ & Value of $F$ & $($ prob $>F)$ \\
\hline \multicolumn{11}{|c|}{ pre-change period } \\
\hline $\begin{array}{l}\text { Error } \\
\text { Dispersion } \\
\end{array}$ & $\begin{array}{r}107.486 \\
12.965 \\
\end{array}$ & $\begin{array}{r}268.528 \\
15.392 \\
\end{array}$ & $\begin{array}{r}163.488 \\
13.813 \\
\end{array}$ & $\begin{array}{r}502.258 \\
13.270 \\
\end{array}$ & $\begin{array}{r}121.505 \\
18.069 \\
\end{array}$ & $\begin{array}{r}231.262 \\
18.347 \\
\end{array}$ & $\begin{array}{l}82.324 \\
10.078 \\
\end{array}$ & $\begin{array}{r}147.620 \\
14.253 \\
\end{array}$ & $\begin{array}{l}1.03 \\
2.65 *\end{array}$ & $\begin{array}{l}(0.3605) \\
(0.0754) \\
\end{array}$ \\
\hline \multicolumn{11}{|c|}{ in-change period } \\
\hline $\begin{array}{l}\text { Error } \\
\text { Dispersion } \\
\end{array}$ & $\begin{array}{l}96.581 \\
15.723 \\
\end{array}$ & $\begin{array}{r}184.792 \\
17.184 \\
\end{array}$ & $\begin{array}{l}59.096 \\
15.326 \\
\end{array}$ & $\begin{array}{l}69.161 \\
19.255 \\
\end{array}$ & $\begin{array}{r}111.726 \\
25.093 \\
\end{array}$ & $\begin{array}{r}130.133 \\
21.598 \\
\end{array}$ & $\begin{array}{l}48.008 \\
11.307 \\
\end{array}$ & $\begin{array}{l}49.110 \\
11.275 \\
\end{array}$ & $\begin{array}{l}3.58 * * \\
2.65 *\end{array}$ & $\begin{array}{l}(0.0308) \\
(0.0744) \\
\end{array}$ \\
\hline \multicolumn{11}{|c|}{ post-change period } \\
\hline $\begin{array}{l}\text { Error } \\
\text { Dispersion }\end{array}$ & $\begin{array}{l}94.206 \\
15.443 \\
\end{array}$ & $\begin{array}{r}232.925 \\
16.803 \\
\end{array}$ & $\begin{array}{l}90.615 \\
14.219 \\
\end{array}$ & $\begin{array}{r}158.290 \\
14.541 \\
\end{array}$ & $\begin{array}{r}214.608 \\
30.126 \\
\end{array}$ & $\begin{array}{r}416.509 \\
21.707 \\
\end{array}$ & $\begin{array}{r}41.223 \\
9.049 \\
\end{array}$ & $\begin{array}{r}58.846 \\
9.489 \\
\end{array}$ & $\begin{array}{l}4.70 * * \\
9.22 * *\end{array}$ & $\begin{array}{l}(0.0108) \\
(0.0002) \\
\end{array}$ \\
\hline
\end{tabular}

* significant at the $10 \%$ level

** significant at the $5 \%$ level

1 Sub-groups are based on the ratio between cash flows from operating activities and earnings (net losses).

2 Null hypothesis $\left(\mathrm{H}_{0}\right)$

Error/Dispersion low quality = Error/Dispersion high quality = Error/Dispersion acceptable quality 
A comparison between the two sub-groups located at the two extremities indicates that it is more difficult to predict the future earnings of enterprises with a high quality of earnings. In other words, when the enterprise's cash flows are positive and high compared with earnings, the forecast is significantly the least exact and the most widely dispersed. One does not expect to find oneself saying that it is those enterprises that are considered to be in the best financial health that create the most difficulty for financial analysts. This is all the more surprising since previous research has focused mainly on the other end of the scale for those firms that have the lowest level of cash flows. When enterprises have a low quality of earnings, financial analysts seem to find it significantly easier to predict future earnings. However, the fact that forecasts for these enterprises are less accurate and more widely dispersed than forecasts for those with an acceptable quality of earnings, does provide a postiori confirmation of the need for more in-depth investigation of the group of enterprises facing financial difficulties.

\subsection{Results of tests of hypotheses}

The results of the tests of hypotheses regarding comparison of the level of error and dispersion in financial analysts' forecasts, between the periods contiguous to the change in policies, will be found in Table 2. The results are given for the overall sample enterprises, and then for each of the three sub-groups. When carrying out these tests, it seemed important to take into account the specific framework of the study, which was to compare the same variable (error and dispersion) over time for the same group of enterprises. This means that we need to use a multivariate analysis that will allow data adjustment based on their inherent correlation, i.e. a repeated measurement analysis of variance. The Greenhouse-Geisser test of significance was used because it is the most conservative of tests available in such situations. It is a Fisher (prob>F) test adjusted for correlation between variables, when present.

The initial test is a comparison between three periods, (pre-change, in-change and post-change) expressed as $\left(\mathrm{H}^{1} \mathrm{~A}-\mathrm{B}\right)$. This first test is the most rigorous since any rejection will mean that there is a significant difference between the three periods, when each one is compared to the other. Subsequently, the tests are repeated taking into account two periods at a time, i.e. pre-change compared with in-change $\left(\mathrm{H}^{2} \mathrm{~A}-\mathrm{B}\right)$, pre-change with post-change $\left(\mathrm{H}^{3} \mathrm{~A}-\mathrm{B}\right)$, then in-change with post-change $\left(\mathrm{H}^{4} \mathrm{~A}-\mathrm{B}\right)$. This methodology is related to that used in previous research, focused mainly on a comparison between two periods.

\subsection{Forecast error $\left(\mathbf{H}_{\mathbf{A}}\right)$}

With regard to the overall sample, Table 2 shows that the forecast error level is not significantly different from one period to another when the three periods are compared with each other. However, the forecast error is significantly lower during the in-change period when compared to the pre-change period. This result confirms that there is some impact of cash flow information on financial analysts' forecasts of future earnings. This result links up with those of previous studies, such as Lobo, Kwon and Ndubizu (1998) and Chaney, Hogan and Debra (1999), in which the relationship between the publication of new accounting information and forecast accuracy was examined.

The above discussion may be further defined by observing the results obtained when the sample is split into sub-groups. Enterprises with an acceptable quality of earnings are the only ones in which the forecast error is significantly lower as of the period in which policies are changed. It should be remembered that the forecasts for this sub-group of enterprises was already significantly more accurate (and less dispersed) than any of the others (Table 1). It would appear that a more balanced ratio of cash flows to earnings made it easier to assess future earnings, and that this became even easier once the new policies on cash flow information were introduced. In fact, the significant lessening of dispersion in enterprise forecasts, following the change in policies $\left(\mathrm{H}^{4} \mathrm{~B}\right)$, rounds out this idea neatly. With regards to enterprises with an acceptable quality of earnings, the impact of cash flow information can be considered as significant, since the forecasts have become both more accurate and less dispersed since the change in policies. It is even more interesting to note that this impact is to be found in firms where financial analysts already have the greatest forecasting capacity (and the highest level of homogeneity). 
Table 2

Comparison of Predictive Error and Dispersion

Between pre-change, in-change and post-change periods

\begin{tabular}{|c|c|c|c|c|c|c|}
\hline Null hypotheses $\left(\mathrm{H}_{0}\right)$ : & & & $\begin{array}{l}\text { overall } \\
\text { sample } \\
\end{array}$ & $\begin{array}{l}\text { low quality } \\
\text { of earnings } 1\end{array}$ & $\begin{array}{l}\text { high quality } \\
\text { of earnings } 1\end{array}$ & $\begin{array}{c}\text { acceptable quality } \\
\text { of earnings } 1 \\
\end{array}$ \\
\hline $\begin{array}{l}\text { Error }_{\text {pre- }}=\text { Error }_{\text {in- }} \\
\quad=\text { Error }_{\text {post- }}\end{array}$ & $\begin{array}{l}\text { Value of } F \\
(\text { prob }>F)\end{array}$ & $\mathrm{H}^{1} \mathrm{~A}$ & $\begin{array}{c}1.28 \\
(0.2793)\end{array}$ & $\begin{array}{c}0.60 \\
(0.4744)\end{array}$ & $\begin{array}{c}0.97 \\
(0.3625)\end{array}$ & $\begin{array}{c}4.10 * * \\
(0.0353)\end{array}$ \\
\hline Error $_{\text {pre- }}=$ Error $_{\text {in }}$ & $\begin{array}{l}\text { Value of } F \\
(\text { prob }>F)\end{array}$ & $\mathrm{H}^{2} \mathrm{~A}$ & $\begin{array}{c}2.96 * \\
(0.0882)\end{array}$ & $\begin{array}{c}0.87 \\
(0.3625)\end{array}$ & $\begin{array}{c}0.13 \\
(0.7211)\end{array}$ & $\begin{array}{l}4.87 * * \\
(0.0313)\end{array}$ \\
\hline Error $_{\text {pre- }}=$ Error $_{\text {post- }}$ & $\begin{array}{l}\text { Value of } F \\
(\text { prob }>F)\end{array}$ & $\mathrm{H}^{3} \mathrm{~A}$ & $\begin{array}{c}0.19 \\
(0.6645)\end{array}$ & $\begin{array}{c}0.36 \\
(0.5567)\end{array}$ & $\begin{array}{c}0.80 \\
(0.3799)\end{array}$ & $\begin{array}{l}4.14 * * \\
(0.0465)\end{array}$ \\
\hline Error $_{\text {in- }}=$ Error $_{\text {post- }}$ & $\begin{array}{l}\text { Value of } F \\
(\text { prob }>F)\end{array}$ & $\mathrm{H}^{4} \mathrm{~A}$ & $\begin{array}{c}1.60 \\
(0.2092) \\
\end{array}$ & $\begin{array}{c}0.62 \\
(0.4415) \\
\end{array}$ & $\begin{array}{c}1.44 \\
(0.2421) \\
\end{array}$ & $\begin{array}{c}0.22 \\
(0.6403) \\
\end{array}$ \\
\hline $\begin{array}{c}\text { Dispersion }_{\text {pre- }}=\text { Dispersion }_{\text {in- }} \\
=\text { Dispersion }_{\text {post- }}\end{array}$ & $\begin{array}{l}\text { Value of } F \\
(\text { prob }>F)\end{array}$ & $\mathrm{H}^{1} \mathrm{~B}$ & $\begin{array}{c}1.93 \\
(0.1471)\end{array}$ & $\begin{array}{c}0.20 \\
(0.8154)\end{array}$ & $\begin{array}{c}2.76 * \\
(0.0514)\end{array}$ & $\begin{array}{c}1.17 \\
(0.3089)\end{array}$ \\
\hline Dispersion $_{\text {pre- }}=$ Dispersion $_{\text {in- }}$ & $\begin{array}{l}\text { Value of } F \\
(\text { prob }>F)\end{array}$ & $\mathrm{H}^{2} \mathrm{~B}$ & $\begin{array}{c}3.63 * \\
(0.0597)\end{array}$ & $\begin{array}{c}0.38 \\
(0.5465)\end{array}$ & $\begin{array}{c}3.20 * \\
(0.0858)\end{array}$ & $\begin{array}{c}0.61 \\
(0.4365)\end{array}$ \\
\hline Dispersion $_{\text {pre- }}=$ Dispersion $_{\text {post- }}$ & $\begin{array}{l}\text { Value of } F \\
(\text { prob }>F)\end{array}$ & $\mathrm{H}^{3} \mathrm{~B}$ & $\begin{array}{c}2.16 \\
(0.1449)\end{array}$ & $\begin{array}{c}0.09 \\
(0.7731)\end{array}$ & $\begin{array}{c}5.67 * * \\
(0.0252)\end{array}$ & $\begin{array}{c}0.39 \\
(0.5334)\end{array}$ \\
\hline Dispersion $_{\text {in- }}=$ DispersionN $_{\text {post- }}$ & $\begin{array}{l}\text { Value of } F \\
(\text { prob }>F)\end{array}$ & $\mathrm{H}^{4} \mathrm{~B}$ & $\begin{array}{c}0.07 \\
(0.7878)\end{array}$ & $\begin{array}{c}0.13 \\
(0.7724)\end{array}$ & $\begin{array}{c}0.73 \\
(0.4014)\end{array}$ & $\begin{array}{c}3.70 * \\
(0.0601)\end{array}$ \\
\hline
\end{tabular}

* $\quad$ significant at the $10 \%$ level

** significant at the 5\% level

Sub-groups are based on the ratio between cash flows from operating activities and earnings (net losses). 
One might have expected the new policies to have a greater effect on enterprises with a low or high quality of earnings, given the higher ratio (negative or positive) between cash flows and earnings. In fact, the forecast error is not significantly different between the periods contiguous to policy changes for the two groups at either extreme. It is surprising that the forecasting ability of financial analysts has not changed following the improved presentation of cash flow information. In these more extreme situations, as described by Bradbury and Newby (1989), it is possible that the new policy has simply allowed financial analysts to reduce the time spent on the analysis without allowing them to generate better forecasts.

To conclude, it would appear that the new cash flow information policies have made it possible for financial analysts to provide more exact forecasts of future earnings, especially with regard to enterprises having an acceptable quality of earnings. It would then appear plausible to suppose that financial analysts found it difficult previously to reconcile cash flow information, or simply that they did not bring the new approach to bear on this information. The presentation of more precise and better-structured information seems to have enabled financial analysts to better integrate it into their analyses.

\subsection{Forecast dispersion $\left(\mathrm{H}_{B}\right)$}

With regard to the sample as a whole, Table 2 indicates that, when the three periods are compared with one another, forecast dispersion is not significantly different from one period to the next. However, the dispersion is significantly greater during the period of policy changes, compared with the pre-change period, as already indicated by Elliott and Philbrick (1990). This result does support the idea that the determination of future earnings may have been influenced by the introduction of new cash flow information policies. This is all the more interesting since the most recent research has concentrated mainly on forecast accuracy, and not dispersion.

Forecast dispersion has been significantly higher since the change in policies amongst the sub-groups of enterprises with a higher quality of earnings. It will be noted that the forecasts for these enterprises are already significantly more dispersed (and less accurate) than those for the other sub-groups, irrespective of period (pre-change, inchange, post-change (Table 1)). It is as if a high ratio of cash flows to earnings led to greater disparity amongst financial analysts' forecasts, and that this imbalance became even more pronounced with the change in policies. Finally, it is strange that the results point to enterprises that are considered to be amongst the best-provided when it comes to cash flows, and yet which are almost completely disregarded by researchers. On the other hand, forecast dispersion amongst enterprises with a low quality of earnings does not significantly differ from one to other of the periods under study. In other words, the forecasting capacity and the homogeneity of beliefs regarding these enterprises appears to be the same during the three periods contiguous to the change in policies. Once again, this is surprising since one might have expected that cash flow information would become more critical in this extreme context and would more greatly affect enterprises experiencing financial difficulties.

Finally, it seems that the new cash flow information policies have led to greater dispersion in future earnings forecasts, more especially for enterprises with a high quality of earnings. It would therefore seem plausible to believe that the publication of more precise and better-structured cash flow information has caused financial analysts to reassess their beliefs. Perhaps, prior to the change in policies, these major market users of information did not take this information into full account when implementing their analyses. The very fact of seeing more heterogeneous beliefs (less dispersion) may mean that all financial analysts may not necessarily have interpreted the information in the same way.

\section{Conclusion}

The objective of this study was to examine the impact on financial analysts' forecast of the change in policies affecting cash flow information. The context is quite specific, since it concerns a more precise and betterstructured presentation of the same accounting information. We have compared the error and dispersion level of future earnings forecasts between the periods contiguous to the change in policies. Moreover, in order to consider the quality of earnings, the sample was divided into three sub-groups representing enterprises with a low quality of earnings, a high quality of earnings, and an acceptable quality of earnings. 
The new cash flow information policies seem to have allowed financial analysts to generate more accurate forecasts for future earnings of the sample group of enterprises as a whole, more especially with regard to those having an acceptable quality of earnings. This improvement in forecasting ability may mean that financial analysts previously found it difficult to reconcile cash flow information or to fully integrate it into their analyses. It should also be noted that the new policies have led to an increase in future earnings forecast dispersion for the sample enterprises as a whole, and more particularly for those with a high quality of earnings. It would appear plausible to believe that the new policies have led to a re-assessment of beliefs amongst financial analysts, possibly with regard to the way in which the new information is interpreted. Given these results, the more precise and better-structured publication of the same cash flow information has had an impact on this sophisticated group of accounting information users.

\section{Suggestions for future research}

In this study, the policy changes under discussion may for the most part be seen as cosmetic, since they deal with a different way of presenting the same information. Given the high-profile impact of this new presentation, accounting policy-making bodies should be asking more questions regarding the requirements of this approach. There is an argument for preferring a more accurate and better-structured presentation of the same information, but a more far-reaching study of this aspect is called for.

This study may be differentiated from others by the fact that it considers cash flow information in order to determine the quality of earnings. Unlike previous studies, that focussed principally on contexts involving enterprises experiencing financial difficulties, the results of our work point rather to enterprises that distinguish themselves by the high quality of their earnings. It would be interesting to find an explanation as to why the forecast ability of financial analysts seems less certain in such situations.

\section{Endnotes}

1. Changes to Canadian policy with regard to cash flows introduced in 1985 are essentially the same as those adopted by the SFAS 95 in 1987.

2. The following assumption was put forward: the annual financial statements were published during the second month following the end of the period, or their contents were otherwise made known during the same month. This assumption was required because the publication date of annual financial statements is not available in the data base used in this research, i.e. the "Stock Guide". Wilson (1987) mentions that annual financial statements are released 5 to 10 weeks after the close of the period. In fact, all the results obtained are the same when the forecasts used are those published during the third and fourth months following the end of the financial period..

3. The sign of this ratio (coefficient) is determined to be as the cash flows, whether the enterprise generates earnings or suffers losses. In other words, a positive (negative) sign means that the cash flows are positive (negative). A coefficient between -1 and 1 (outside the interval of -1 and 1) means that the cash flows from operating activities are less (more) than the figure of the net earnings (net losses as an absolute value).

4. More specifically, the coefficient of the ratio of cash flows from operating activities to net earnings (net losses) is from -11.4 to -2.8 for enterprises with a low quality of earnings, from -2.9 à 2.1 for enterprises with an acceptable quality of earnings and from 2.2 à 14.7 for enterprises with a high quality of earnings.

5. In line with Wilson (1987) and Stickel (1989), outlier sample values were eliminated in order to avoid the potential impact ("white noise") from some extreme observations that could unfairly bias the results.

\section{References}

1. Ali, A., "The Incremental Information Content of Earnings, Working Capital from Operations and Cash Flows", Journal of Accounting Research, Vol. 32, No. 1, pp. 61-74, 1994.

2. Ali, A., Klein, A. and Rosenfeld, J., "Analysts' Use of Information about Permanent and Transitory Earnings Components in Forecasting Annual EPS", The Accounting Review, Vol. 67, No. 1, pp. 183-198, 1992.

3. Ashbaugh, H. and Pincus, M., "Domestic Accounting Standards, International Accounting Standards, and Predictability of Earnings", Journal of Accounting Research, Vol. 39, No. 3, pp. 417-434, 2001.

4. Atrill, P., "Profit is not Enough", Accountancy, Vol. 127, No. 1293, pp. 134-136, 2001. 
5. Barlev, B. and Livnat, J., "The Information Content of Funds Statement Ratios", Journal of Accounting, Auditing and Finance, pp. 411-438, 1990.

6. Bernard, V. L. and Stober, T. L., "The Timing, Amount, and Nature of Information Reflected in Cash Flows and Accruals", The Accounting Review, Vol. 64, No. 4, pp. 624-652, 1989.

7. Biddle, G. C. and Ricks, W. E., "Analyst Forecast Errors and Stock Price Behavior Near the Earnings Announcement Dates of LIFO Adopters", Journal of Accounting Research, Vol. 26, No. 2, pp. 161-234, 1988.

8. Bowen, R. M., Burgstahler, D. and Daley, L. A., "The Incremental Information of Accrual Income Versus Cash Flows", The Accounting Review, Vol. 62, No. 4, pp. 723-747, 1987.

9. Boyd, T. and Cortese-Danile, T. M., "Using the Cash Flow Statement to Improve Credit Analysis", Commercial Lending Review, Vol. 16, No. 1, pp. 55-59, 2001.

10. Bradbury, M. and Newby, S., "The Use of a Statement of Changes in Financial Position to Interpret Financial Data: An Empirical Investigation”, Abacus, pp. 31-38, 1989.

11. Brown, L. D. and Han, J. C. Y., "The Impact of Annual Earnings Announcements on Convergence of Beliefs", The Accounting Review, Vol. 67, No. 4, pp. 862-875, 1992.

12. Brown, L. D., Richardson, G. D. and Schwager, S. J., "An Information Interpretation of Financial Analyst Superiority in Forecasting Earnings", Journal of Accounting Research, Vol. 25, No. 1, pp. 49-67, 1987.

13. Canadian Institute of Chartered Accountants (CICA). Financial Reporting in Canada.

14. Chaney, P. K., Hogan, C. E. and Jeter, D. C.,'The Effect of Reporting Restructuring Charges on Analysts' Forecast Revisions and Errors", Journal of Accounting and Economics, Vol. 27, No.3, pp. 261-284, 1999.

15. Charitou, A., Clubb, C. and Andreas, A., "The Effect of Earnings Permanence, Growth and Firm Size on the Usefulness of Cash Flows and Earnings in Explaining Security Returns : Empirical Evidence for the UK", Journal of Business, Finance and Accounting, Vol. 28, No. 5/6, pp. 563-594, 2001.

16. Cheng, C. S. A., Liu, C. and Schaefer, T. F., "The Value-Relevance of SFAS No. 95 Cash Flows from Operations as Assessed by Security Market Effects", Accounting Horizons, Vol. 11, No. 3, pp. 1-15, 1997.

17. Drtina, R. E. and Largay, J. A., "Pitfalls in Calculating Cash Flows from Operations", The Accounting Review, Vol. 60, No. 2, pp. 314-326, 1985.

18. Elliott, J. A. and Philbrick, D. R., "Accounting Changes and Earnings Predictability", The Accounting Review, Vol. 65, No. 1, pp. 157-194, 1990.

19. Financial Accounting Standards Board. "Statement of Financial Accounting Standards No. 95” (SFAS 95), Statement of Cash Flows, 1987.

20. Hanna, J.D. Financial Distress and Unexpected Cash-Flows, University of Waterloo, working paper, 1993.

21. Healy, P. M. and Palepu, K. G., "The Effects of Firms' Financial Disclosure Strategies on Stock Prices", Accounting Horizons, Vol. 7, No. 1, pp. 1-11, 1993.

22. Huyghebaert, N., Gaeremynck, A., Roodhooft, F. and Van de Gucht, L. M., "New Firm Survival : The Effects of Start-up Characteristics", Journal of Business, Finance and Accounting, Vol. 27, No. 5/6, pp. 627$651,2000$.

23. Hugues, J. S. and Ricks, W. E., "Market Reactions to Mandated Interest Capitalization", Contemporary Accounting research, Vol. 25, No. 1, pp. 222-241, 1986.

24. Kochanek, R. F. and Norgaard, C. T., "Analysing the Components of Operating Cash Flow: The Charter Company", Accounting Horizons, Vol. 2, No. 1, pp. 58-66, 1988.

25. Kross, W., Ro, B. and Schroeder, D., "Earnings Expectations: The Analysts' Information Advantage", The Accounting Review, Vol. 65, No. 2, pp. 461-476, 1990.

26. Lobo, G. J., Kwon, S. S. and Ndubizu, G. A., "The Impact of SFAF No. 14 Segment Information on Price Variability and Earnings Forecast Accuracy", Journal of Business, Finance and Accounting, Vol. 25, No. 7/8, pp. 969-985, 1998.

27. Maksy, M. M., "Articulation Problems Between the Balance Sheet and the Funds Statement", The Accounting Review, Vol. 63, No. 4, pp. 683-699, 1988.

28. McEwen, R. A. and Hunton, J. E., "Is Analyst Forecast Accuracy Associated with Accounting Information Use ?", Accounting Horizons, Vol. 13, No. 1, pp. 1-16, 1999.

29. Mills, J., Bible, L. and Mason, R., "Defining Free Cash Flow”, The CPA Journal, Vol. 72, No. 1, pp. 36-42, 2002.

30. Neill, J. D., Schaefer, T. F., Bahnson, P. R. and Bradbury, M. E., "The Usefulness of Cash Flow Data: A Review and Synthesis", Journal of Accounting Literature, Vol. 10, pp. 117-150, 1991. 
31. O'glove, T. L., Quality of Earnings: The Investor's Guide to How Much Money a Company is Really Making, The Free Press, New York, 1987.

32. Ricks, W. E. and Hugues, J. S., "Market Reactions to a Non-Discretionary Accounting Change: The Case of Long-Term Investments", Journal of Accounting Research, Vol. 23, No. 1, pp. 33-52, 1985.

33. Rujoub, M. A., Cook, D. M. and Hay, L. E., "Using Cash Flow Ratio to Predict Business Failures", Journal of Mathematical Economic, Vol. 7, No. 1, pp. 75-83, 1995.

34. Sondhi, A. C., Sorter, G. H. and White, G. I., "Transactional Analysis”, Financial Analysts Journal, pp. 5764, 1987.

35. Stickel, S. E., "Predicting Individual Analyst Earnings Forecasts", Journal of Accounting Research, Vol. 11, pp. 409-417, 1989.

36. Swaminathan, S., "The Impact of SEC Mandated Segment Data on Price Variability and Divergence of Beliefs", The Accounting Review, Vol. 66, No. 1, pp. 23-41, 1991.

37. Tergesen, A., "The Ins and Outs of Cash Flow", Business Week, January 22, pp. 102-104, 2001.

38. Wilson, G. P., "The Incremental Information Content of Accruals and Cash Flows after Controlling for Earnings", The Accounting Review, Vol. 62, No. 2, pp. 293-322, 1987.

Notes 
Notes 